Article

\title{
Toxic Metal Adsorption from Aqueous Solution by Activated Biochars Produced from Macadamia Nutshell Waste
}

\author{
Minh Trung Dao ${ }^{1}$, T. T. Tram Nguyen ${ }^{1}$, X. Du Nguyen ${ }^{2}$, D. Duong La ${ }^{3,4, *}$, \\ D. Duc Nguyen ${ }^{5,6, *(\mathbb{D}) \text {, S. W. Chang }}{ }^{6}$, W. J. Chung ${ }^{6}$ and Van Khanh Nguyen ${ }^{7, *(\mathbb{D})}$ \\ 1 Thu Dau Mot University, Thu Dau Mot City, Binh Duong Province, Vietnam; \\ trungdm@tdmu.edu.vn (M.T.D.); tramntt@tdmu.edu.vn (T.T.T.N.) \\ 2 Saigon University, Ho Chi Minh City, Vietnam; nxdu@sgu.edu.vn \\ 3 Laboratory of Advanced Materials Chemistry, Advanced Institute of Materials Science, \\ Ton Duc Thang University, Ho Chi Minh City, Vietnam \\ 4 Faculty of Applied Sciences, Ton Duc Thang University, Ho Chi Minh City, Vietnam \\ 5 Institute of Research and Development, Duy Tan University, Da Nang 550000, Vietnam \\ 6 Department of Environmental Energy Engineering, Kyonggi University, Suwon 16227, Korea; \\ swchang@kyonggi.ac.kr (S.W.C.); cine23@kyonggi.ac.kr (W.J.C.) \\ 7 Department of Microbiology, Pusan National University, Busan 46241, Korea \\ * Correspondence: laducduong@tdtu.edu.vn (D.D.L.); nguyendinhduc2@duytan.edu.vn (D.D.N.); \\ khanhnv88@pusan.ac.kr (V.K.N.)
}

Received: 20 August 2020; Accepted: 22 September 2020; Published: 24 September 2020

\begin{abstract}
Abundantly available biomass wastes from agriculture can serve as effective environmental remediation materials. In this study, activated biochar was fabricated from macadamia nutshell (MCN) through carbonization and chemical modification. The resultant biochars were used as adsorbents to remove toxic metal ions such as $\mathrm{Cu}^{2+}$ and $\mathrm{Zn}^{2+}$ from aqueous solutions. The results showed that the activated MCN biochar has a high adsorption capacity for toxic metal ions. When MCN biochar was activated with $\mathrm{K}_{2} \mathrm{CO}_{3}$, the adsorption efficiencies for $\mathrm{Cu}^{2+}$ and $\mathrm{Zn}^{2+}$ were $84.02 \%$ and $53.42 \%$, respectively. With $\mathrm{H}_{3} \mathrm{PO}_{4}$ activation, the $\mathrm{Cu}^{2+}$ - and $\mathrm{Zn}^{2+}$-adsorption performances were $95.92 \%$ and $67.41 \%$, respectively. $\mathrm{H}_{2} \mathrm{O}_{2}$-modified $\mathrm{MCN}$ biochar had reasonable $\mathrm{Cu}^{2+}$ - and $\mathrm{Zn}^{2+}$-adsorption efficiencies of $79.33 \%$ and $64.52 \%$, respectively. The effects of $\mathrm{pH}$, adsorbent concentration and adsorption time on the removal performances of $\mathrm{Cu}^{2+}$ and $\mathrm{Zn}^{2+}$ in aqueous solution were evaluated. The results exhibited that the activated MCN biochar showed quick adsorption ability with an optimal $\mathrm{pH}$ of 4 and 4.5 for both $\mathrm{Cu}^{2+}$ and $\mathrm{Zn}^{2+}$, respectively.
\end{abstract}

Keywords: toxic metals removal; biochar; macadamia nutshell; adsorption; activated carbon

\section{Introduction}

The rapid and continuous growth of industrialization and urbanization has caused serious environmental problems. Of these, contamination of water sources with toxic metals has attracted considerable interest from scientists and governments worldwide. Toxic metal ions-even at trace levels—can be extremely harmful to human health and ecosystems [1,2]. Therefore, the removal of toxic metal ions from aqueous solutions requires urgent attention. Many techniques have been effectively used for the removal of toxic metals ions from polluted wastewater, including, but not limited to, precipitation, use of filtration membranes, chemical treatment, reverse osmosis, electrochemical treatment and adsorption [3-5]. Among these methods, adsorption has been demonstrated as an effective pathway for the removal of toxic ions from contaminated water because of its low operation cost, high performance and simplicity. 
Many materials and resources have been employed as adsorbents. For example, biomass waste, industrial waste, carbon-based nanomaterials, oxides, natural and synthetic polymers and surfactants have been used for remediation of toxic metal contamination [6-8]. Biochar, a common carbon-based group of nanomaterials derived from biomass, has a microporous structure with high surface area, many reactive sites on the surface and high adsorption capacity [9], and therefore, it is extensively used as an effective and affordable adsorbent of metal ions [10]. Biochar is obtained from the thermochemical decomposition of biomass [11,12]. The factors that decide the quality of biochar products are heat treatment time, temperature, type of natural resources and limited oxygen condition [13]. Abundant natural wastes such as cocoa husks, corn cob, rice husks, sludge, coconut shell, seeds, fruits, straws, leaves, orange peel, and other residuals are used to produce biochar for the effective removal of toxic metal ions [14-16].

The macadamia nut was first discovered in Southern Australia by botanists in 1857, and thereafter, it has been widely grown worldwide as a high-value agricultural product. Approximately $70-77 \%$ of a macadamia nut is the nutshell, which means that one ton of macadamia kernel produces an average of approximately three tons of nutshell [17]. With an annual estimated production of 44,000 tons of macadamia kernels, more than 120,000 tons of macadamia nutshell are discarded as solid waste per annum. This large amount of solid waste needs to be treated-or could be used for various applications [18]. One of the important recycling processes of macadamia nutshell is to produce biochar, which is used as activated carbon for adsorption or charcoal for heating purposes [19,20]. With high surface area and carbon content, the carbon material produced from the macadamia nutshell is of lower ash content than that of other biomass materials. Macadamia-derived biochar has been successfully employed in various applications such as when combined with other types of biochars to form denitrification agents in bioreactors [21], for soil amendment and nutrient control in agriculture [22,23] and for the production of steel [24]. In order to enhance the surface area of the biochar, which increases the adsorption capacity, the biochar has to activate either by physical or chemical methods. Among these, chemical activations. Among these, chemical activation is one of the most favorites techniques to obtain the desirable adsorption capability of biochar for the pollutant treatment in practical $[25,26]$. Rodrigues et al. also fabricated activated carbon from macadamia nutshell and used it as an adsorbent for the effective removal of organic solvents such as phenol [27]. The macadamia-based biochars were also successfully employed for the removal of toxic metal ions [28-32]. However, the application of macadamia nutshell-derived biochar solely for the removal of $\mathrm{Zn}^{2+}$ and $\mathrm{Cu}^{2+}$ seems to be scarce. Furthermore, the need for finding an effective activation and/or chemical modification protocol to produce activated carbon from the macadamia nutshell is crucial.

Thus, this work presents an effective protocol to fabricate chemically modified biochar from macadamia nutshells through carbonization and chemical activation. In these works, the common and widely available basic chemicals such as $\mathrm{K}_{2} \mathrm{CO}_{3}, \mathrm{H}_{3} \mathrm{PO}_{4}$ and $\mathrm{H}_{2} \mathrm{O}_{2}$ were used to activate the MCN biochar. The resultant biochar is employed as an adsorbent for the removal of $\mathrm{Cu}^{2+}$ and $\mathrm{Zn}^{2+}$ from an aqueous solution. The effects of several factors on the adsorption performance such as $\mathrm{pH}$ of the solution, concentration, and adsorption time were investigated in detail.

\section{Materials and Methods}

\subsection{Materials}

Stock solutions of $\mathrm{Cu}^{2+}$ and $\mathrm{Zn}^{2+}$ with concentrations of 30 ppm each, $\mathrm{K}_{2} \mathrm{CO}_{3}, \mathrm{H}_{3} \mathrm{PO}_{4}$ and $\mathrm{H}_{2} \mathrm{O}_{2}$ were purchased from Xilong Scientific Co., Ltd., Shantou, China. Macadamia nutshells (MCN) were obtained as biomass waste from the Lam Dong Province, Vietnam. All chemicals (except macadamia nutshells) were used as received without any purification. 


\subsection{Fabrication of Modified MCN Biochar from Macadamia Nutshells}

Macadamia nutshells were collected as biomass waste and then washed thoroughly and dried before the carbonization process. Typically, MCN nutshells with uniform size were cleaned and thoroughly rinsed with distilled water, then dried at a temperature of $110^{\circ} \mathrm{C}$ for $48 \mathrm{~h}$. After primary treatment, the $\mathrm{MCN}$ nutshells were calcined at a temperature of $350^{\circ} \mathrm{C}$ for $1 \mathrm{~h}$ with a heating rate of $23^{\circ} \mathrm{C}$ per minute to form MCN charcoal.

$\mathrm{K}_{2} \mathrm{CO}_{3}$-modified $\mathrm{MCN}$ biochar: $\mathrm{MCN}$ charcoal was immersed and agitated in $\mathrm{K}_{2} \mathrm{CO}_{3}$ solution with a charcoal: $\mathrm{K}_{2} \mathrm{CO}_{3}$ :water ratio of 1:1:10 for $24 \mathrm{~h}$. The precipitate was filtered and dried at $110{ }^{\circ} \mathrm{C}$ for $24 \mathrm{~h}$. The $\mathrm{K}_{2} \mathrm{CO}_{3}$-modified $\mathrm{MCN}$ charcoal was then carbonized in the furnace for $1 \mathrm{~h}$ at a temperature of $650{ }^{\circ} \mathrm{C}$. The obtained samples were washed thoroughly with distilled water until the $\mathrm{pH}$ reached 7 and then dried at $110{ }^{\circ} \mathrm{C}$. Samples were ground to fine particles and stored in a vacuum for further characterization.

$\mathrm{H}_{3} \mathrm{PO}_{4}$-modified MCN biochar: MCN charcoal was immersed and agitated in $\mathrm{H}_{3} \mathrm{PO}_{4}$ solution for $24 \mathrm{~h}$ with a charcoal: $\mathrm{H}_{3} \mathrm{PO}_{4}$ :water ratio of 1:1:10. The precipitate was filtered and dried at $170{ }^{\circ} \mathrm{C}$ for $1 \mathrm{~h}$. The $\mathrm{K}_{2} \mathrm{CO}_{3}$-modified $\mathrm{MCN}$ charcoal was then carbonized in the furnace for $1 \mathrm{~h}$ at a temperature of $500^{\circ} \mathrm{C}$. The obtained samples were washed thoroughly with distilled water until the $\mathrm{pH}$ reached 7 , then they were dried at $110^{\circ} \mathrm{C}$. Samples were ground to fine particles and stored in a vacuum for further characterization.

$\mathrm{H}_{2} \mathrm{O}_{2}$-modified MCN biochar: MCN charcoal was immersed and agitated in $\mathrm{H}_{2} \mathrm{O}_{2} 25 \%$ solution continuously for $48 \mathrm{~h}$ with charcoal: $\mathrm{H}_{2} \mathrm{O}_{2} 25 \%$ ratio of 1:10. After modification, the samples were washed with distilled water until neutral $\mathrm{pH}$ and dried at a temperature of $110{ }^{\circ} \mathrm{C}$. Samples were ground to fine particles and stored in a vacuum for further characterization.

\subsection{Toxic Metal Adsorption Studies}

Effect of $\mathrm{pH}$ of the solution: The toxic metal ions employed in this study were $\mathrm{Cu}^{2+}$ and $\mathrm{Zn}^{2+}$ with a concentration of $30 \mathrm{ppm}$ each. In the typical experiment, the modified-MCN biochar with a concentration of $0.3 \mathrm{~g} / \mathrm{L}$ was added to $50 \mathrm{~mL}$ of $\mathrm{Cu}^{2+}$ or $\mathrm{Zn}^{2+} 30 \mathrm{ppm}$ with the $\mathrm{pH}$ of the solution adjusted from 2.5 to 5.5. The adsorption time was $1 \mathrm{~h}$. The precipitates were separated, and the residual was used to measure the remaining ions in the solution. The experiments were repeated three times.

Effect of biochar content: The modified-MCN biochar with the concentration ranging from $0.2 \mathrm{~g} / \mathrm{L}$ to $2 \mathrm{~g} / \mathrm{L}$ was added to $50 \mathrm{~mL}$ of $\mathrm{Cu}^{2+}$ or $\mathrm{Zn}^{2+} 30 \mathrm{ppm}$ with the $\mathrm{pH}$ of the solution of 5.5. The adsorption time was $1 \mathrm{~h}$. The precipitates were separated, and the residual was used to measure the remaining ions in the solution. The experiments were repeated three times.

Effect of adsorption time (adsorption kinetics): The modified-MCN biochar with the concentration of $0.3 \mathrm{~g} / \mathrm{L}$ was added to $50 \mathrm{~mL}$ of $\mathrm{Cu}^{2+}$ or $\mathrm{Zn}^{2+} 30 \mathrm{ppm}$ with the $\mathrm{pH}$ of the solution of 5.5. The adsorption time was from $0 \mathrm{~min}$ to $120 \mathrm{~min}$. The precipitates were separated, and the residual was used to measure the remaining ions in the solution. The experiments were repeated three times.

\subsection{Characterization of Biochars}

The infrared absorption spectrum determines the FT-IR molecular functional group using the Perkin Elmer spectrophotometer with a resolution of $2 \mathrm{~cm}^{-1}$ and 16 scans (PerkinElmer, Inc., Waltham, MA, USA). All the spectra were recorded in the transmittance mode [33]. SEM particle size measurement and surface observation were conducted using a scanning electron microscope (SEM; JEOL, Ltd., Tokyo, Japan) at $2.0 \mathrm{kV}$ and $10 \mu \mathrm{A}$. The samples were coated with gold powder before the images were captured. $\mathrm{pH}$ was measured directly using a pH meter (Mettler Toledo-S220K, Mettler Toledo, Greifensee, Switzerland). 


\section{Results and Discussion}

\subsection{SEM Image and FTIR Spectrum of the Modified-MCN Biochar}

The morphology of the prepared modified-MCN biochar was observed using SEM and the result is shown in Figure 1a. It is evident that the prepared modified-MCN biochar has a porous microstructure with an average pore size of $10 \mu \mathrm{m}$. The appearance of the pore structures is due to the etching caused by the activating agent such as $\mathrm{H}_{3} \mathrm{PO}_{4}$ as well as the activating condition at high temperatures. The chemical surface properties of the resultant biochar were investigated using an FTIR spectrum (Figure 1b). In the FTIR spectrum, the appearance of the vibration bands at $700 \mathrm{~cm}^{-1}$ and $400 \mathrm{~cm}^{-1}$ represents the stretching oscillation of the $C=C$ functional group, which indicates that the $\mathrm{C}$ content increases in the biochar [34]. The vibration band at the wavelength of $3426.4 \mathrm{~cm}^{-1}$ is ascribed to the $\mathrm{OH}^{-}$stretching in the functional hydroxyl group, which is favorable for the metal ion adsorption [35]. The functional carbonyl groups $(\mathrm{C}-\mathrm{O}$ and $\mathrm{C}=\mathrm{O})$ on the surface of biochar are also observed in the wavelength range of $1000 \mathrm{~cm}^{-1}$ to $2000 \mathrm{~cm}^{-1}$ of the FTIR spectrum, which indicates that the surface of the MCN biochar was successfully modified with the functional groups thereby improving the adsorption capability of the MCN biochar. The surface area of the modified-MCN biochar was determined to be $339,262 \mathrm{~m}^{2} / \mathrm{g}$, which is reasonable for adsorption application.
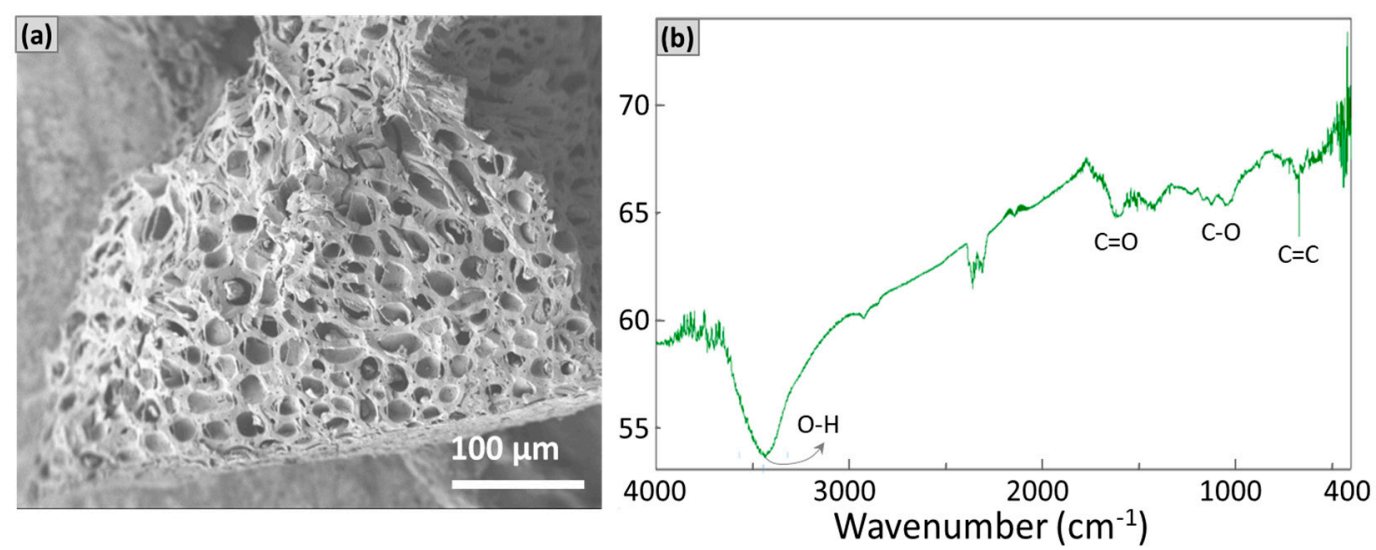

Figure 1. (a) SEM image and (b) FTIR spectrum of the modified-macadamia nutshell biochar.

\subsection{Adsorption of $\mathrm{Cu}^{2+}$ by Modified-MCN Biochar}

It is well-known that the $\mathrm{pH}$ of the solution plays a significant role in the adsorption behavior of the $\mathrm{Cu}^{2+}$, which is related to the dissolution and precipitation of copper [36]. With a $\mathrm{pH}$ of less than 6, copper is mostly present in the aqueous solution as ions, however, when the $\mathrm{pH}$ of the solution $>6$, copper ions tend to precipitate [37]. Thus, to study adsorption behavior, the $\mathrm{pH}$ of the solution of $<6$ was selected. Figure 2 presents the $\mathrm{Cu}^{2+}$ adsorption performance by the modified-MCN biochars with various $\mathrm{pH}$ values of the solution for one hour with the adsorbent dose of $0.3 \mathrm{~g} / \mathrm{L}$. The figure clearly shows that the adsorption capabilities of $\mathrm{Cu}^{2+}$ by $\mathrm{MCN}$ biochars modified with $\mathrm{K}_{2} \mathrm{CO}_{3}, \mathrm{H}_{3} \mathrm{PO}_{4}$ and $\mathrm{H}_{2} \mathrm{O}_{2}$ increases along with an increase in the $\mathrm{pH}$ of the solution. The $\mathrm{Cu}^{2+}$ removal percentages significantly increased from the $\mathrm{pH}$ of the solution of 2.5 to 4 . Further, an increase in $\mathrm{pH}$ from 4-5.5 witnesses a negligible increase in adsorption efficiencies. For the $\mathrm{K}_{2} \mathrm{CO}_{3}$-modified $\mathrm{MCN}$ biochar, the removal percentages of $\mathrm{Cu}^{2+}$ at $\mathrm{pH}$ values of $4,4.5,5$ and 5.5 were $22.66 \%, 28.27 \%, 32.61 \%$ and $33.85 \%$, respectively, indicating that the optimal $\mathrm{pH}$ for $\mathrm{Cu}^{2+}$ removal by the $\mathrm{K}_{2} \mathrm{CO}_{3}$-modified $\mathrm{MCN}$ biochar was 5-5.5. When $\mathrm{Cu}^{2+}$ was absorbed by $\mathrm{H}_{3} \mathrm{PO}_{4}$-modified $\mathrm{MCN}$ biochar, a similar trend in the effect of $\mathrm{pH}$ on the adsorption performance was also observed and the maximum adsorption of ions was $55 \%$ obtained at a $\mathrm{pH}$ of $5-5.5$. Therefore, a $\mathrm{pH}$ of the solution of 5.5 was optimal for the maximum $\mathrm{Cu}^{2+}$ adsorption of $76 \%$. These results are consistent with that of previous studies [38,39]. It is relevant to 
note that the MCN biochar modified by $\mathrm{H}_{2} \mathrm{O}_{2}$ showed the highest $\mathrm{Cu}^{2+}$ removal in comparison with that modified by $\mathrm{K}_{2} \mathrm{CO}_{3}$ and $\mathrm{H}_{3} \mathrm{PO}_{4}$.

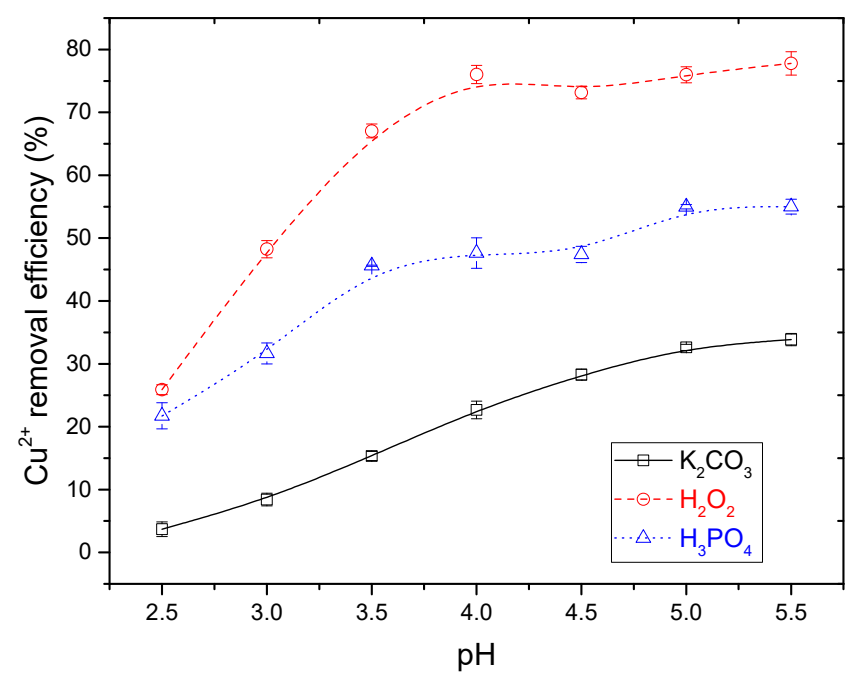

Figure 2. Effect of $\mathrm{pH}$ of the solution on $\mathrm{Cu}^{2+}$ adsorption by chemically modified MCN biochars at the adsorbent dose of $0.3 \mathrm{~g} / \mathrm{L}$ and adsorption time of one hour.

The concentrations of the adsorbents had significant impacts on the $\mathrm{Cu}^{2+}$ and $\mathrm{Zn}^{2+}$ adsorption performances of the activated biochar. Figure 3 shows the $\mathrm{Cu}^{2+}$ adsorption efficiency of chemically modified MCN biochars with a $\mathrm{pH}$ of the solution of 5 and an adsorption time of $1 \mathrm{~h}$. The adsorption capacities of $\mathrm{MCN}$ biochars activated with $\mathrm{K}_{2} \mathrm{CO}_{3}, \mathrm{H}_{2} \mathrm{O}_{2}$ and $\mathrm{H}_{3} \mathrm{PO}_{4}$ increased along with adsorbent concentrations. For the $\mathrm{K}_{2} \mathrm{CO}_{3}$-activated $\mathrm{MCN}$ biochar, the $\mathrm{Cu}^{2+}$ adsorption efficiency increased remarkably with dosed of $0.2-1.4 \mathrm{~g} / \mathrm{L}$. It gradually increased with dosage before reaching the maximum of $84.96 \%$ of $\mathrm{Cu}^{2+}$ removal at the adsorbent concentration of $2 \mathrm{~g} / \mathrm{L}$. Similar trends could also be observed with $\mathrm{H}_{2} \mathrm{O}_{2}$ and $\mathrm{H}_{3} \mathrm{PO}_{4}$-activated $\mathrm{MCN}$ biochars, where the $\mathrm{Cu}^{2+}$ adsorption efficiencies increase with an increase of adsorbent concentrations and reaching a maximum of $80.50 \%$ and $94.53 \%$ at a concentration of $2 \mathrm{~g} / \mathrm{L} \mathrm{H}_{2} \mathrm{O}_{2}$ and $\mathrm{H}_{3} \mathrm{PO}_{4}$-activated $\mathrm{MCN}$ biochars, respectively. With the dose of $2 \mathrm{~g} / \mathrm{L}$, the MCN biochars modified with $\mathrm{H}_{3} \mathrm{PO}_{4}$ exhibited the highest $\mathrm{Cu}^{2+}$ removal efficiency in comparison with that modified with $\mathrm{H}_{2} \mathrm{O}_{2}$ and $\mathrm{K}_{2} \mathrm{CO}_{3}$.

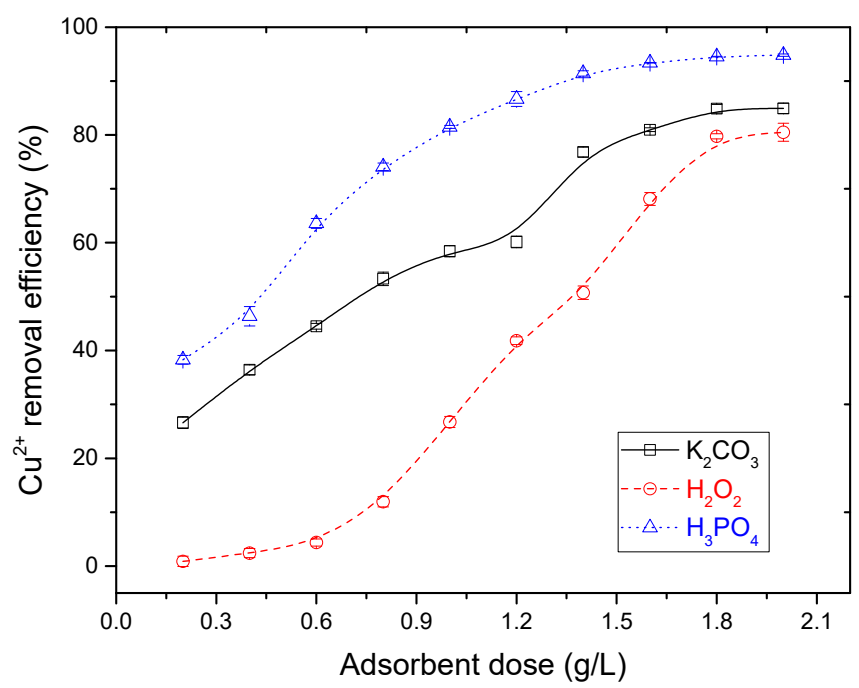

Figure 3. Effects of concentration of chemically modified $\mathrm{MCN}$ biochars on $\mathrm{Cu}^{2+}$ adsorption performance with an adsorption time of one hour and $\mathrm{pH}$ of the solution of 5 . 
Figure 4 shows the effect of adsorption time on the $\mathrm{Cu}^{2+}$ removal efficiencies by the modified $\mathrm{MCN}$ biochars with an adsorbent content of $2 \mathrm{~g} / \mathrm{L}, \mathrm{Cu}^{2+}$ concentration of $30 \mathrm{ppm}$ and solution $\mathrm{pH}$ of 5. It can be clearly seen that the optimal time to adsorb $\mathrm{Cu}^{2+}$ by the $\mathrm{MCN}$ biochars activated with $\mathrm{K}_{2} \mathrm{CO}_{3}$ was $30 \mathrm{~min}$ with an efficiency of $84.02 \%$, which became saturated at $40 \mathrm{~min}$ of processing time at a removal efficiency of $86.35 \%$, after which the treatment efficiency increased insignificantly at $50 \mathrm{~min}$ to $87.85 \%$ and slightly decreased at $1 \mathrm{~h}$ to $87.81 \%$. Research results determined that $\mathrm{pH}=5$, a dosage of $2 \mathrm{~g} / \mathrm{L}$, and a processing time of $30 \mathrm{~min}$ was optimal for treating $\mathrm{Cu}^{2+}$. Thus, it shows that $\mathrm{K}_{2} \mathrm{CO}_{3}$-activated $\mathrm{MCN}$ biochar could be used effectively as an adsorbent for the treatment of toxic $\mathrm{Cu}^{2+}$ in textile wastewater. Badruddoza et al. (2011) [33] found that that after $30 \mathrm{~min}$ of treatment, the processing efficiency of $\mathrm{Cu}^{2+}$ using carboxymethyl-cyclodextrin conjugated magnetic nanoparticles had a similar treatment performance of $90 \%$ removal. Research results from Singha and Das (2013) [40] showed that after $5 \mathrm{~h}$ of treatment, the efficiency of $\mathrm{Cu}^{2+}$ treatment at $\mathrm{pH} 6$ using activated carbon from coconut shell was approximately $90 \%$.

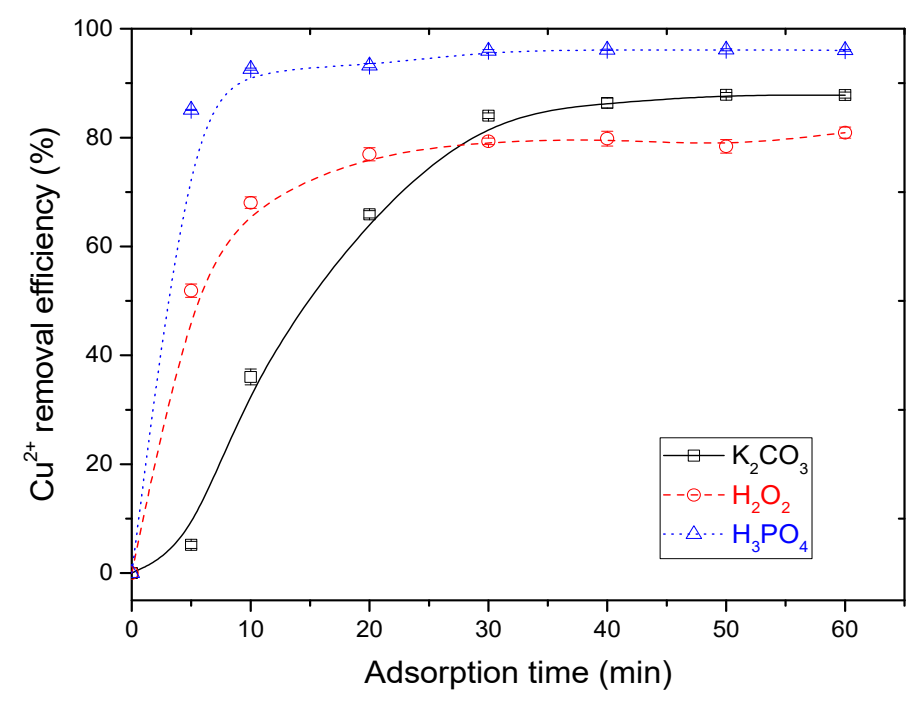

Figure 4. Effect of adsorption time on $\mathrm{Cu}^{2+}$ removal efficiencies using activated MCN biochars with an adsorbent dose of $2 \mathrm{~g} / \mathrm{L}$ at a solution $\mathrm{pH}$ of 5 .

For the MCN biochar modified with $\mathrm{H}_{3} \mathrm{PO}_{4}$ the $\mathrm{Cu}^{2+}$ removal efficiencies with reaction times of 0 , $10,20,30,40,50 \mathrm{~min}$ and one hour were determined to be $0,85.08 \%, 92.58 \%, 93.21 \%, 95.92 \%, 96.12 \%$, $96.14 \%$ and $96.03 \%$, respectively. This indicates that the $\mathrm{H}_{3} \mathrm{PO}_{4}$-activated $\mathrm{MCN}$ biochar has a quick absorbing capability for $\mathrm{Cu}^{2+}$ with the highest efficiency of $96.14 \%$ after $50 \mathrm{~min}$ of adsorption time. When activated with $\mathrm{H}_{2} \mathrm{O}_{2}$, the MCN biochar also reveals fast removal of $\mathrm{Cu}^{2+}$ as $51.58 \%$ is removed only after $10 \mathrm{~min}$. The optimized adsorption time for $\mathrm{Cu}^{2+}$ treatment using $\mathrm{H}_{2} \mathrm{O}_{2}$-activated $\mathrm{MCN}$ biochar is one hour with the highest $\mathrm{Cu}^{2+}$ removal efficiency of $80.9 \%$. It can be concluded that the MCN biochar activated with $\mathrm{H}_{3} \mathrm{PO}_{4}$ and $\mathrm{K}_{2} \mathrm{CO}_{3}$ show faster $\mathrm{Cu}^{2+}$ adsorption efficiencies than that activated with the $\mathrm{H}_{2} \mathrm{O}_{2}$ agent.

\subsection{Adsorption of $\mathrm{Zn}^{2+}$ by Modified-MCN Biochar}

The $\mathrm{pH}$ of the solution had a significant effect on $\mathrm{Zn}^{2+}$ adsorption performance of biochar. Thus, the effect of $\mathrm{pH}$ of the solution on the removal efficiency of $\mathrm{Zn}^{2+}$ by the modified-MCN biochar for one hour with the adsorbent dose of $0.3 \mathrm{~g} / \mathrm{L}$ was investigated as shown in Figure 5. In general, the adsorption capabilities of $\mathrm{Zn}^{2+}$ by $\mathrm{MCN}$ biochars modified with $\mathrm{K}_{2} \mathrm{CO}_{3}, \mathrm{H}_{3} \mathrm{PO}_{4}$, and $\mathrm{H}_{2} \mathrm{O}_{2}$ decreased at a low $\mathrm{pH}$ of the solution of 2 to 3, reached a minimum value at a $\mathrm{pH} 2.5-3$, then significantly increased in a $\mathrm{pH}$ of 3.5-5. The adsorption of $\mathrm{Zn}^{2+}$ by $\mathrm{MCN}$ biochars activated with $\mathrm{K}_{2} \mathrm{CO}_{3}$ decreased with the increase in the $\mathrm{pH}$ of the solution from 2 to 3 and reached a minimal removal concentration of $2.63 \mathrm{ppm}$ at a $\mathrm{pH}$ of 
3. Further increases in the $\mathrm{pH}$ of the solution demonstrated an increase in the adsorption capabilities of biochar; it reached a maximum at the $\mathrm{pH}$ of 4.5 with a removal concentration of $4.85 \mathrm{ppm}$. A similar trend was also observed with the adsorption behaviors of the $\mathrm{H}_{2} \mathrm{O}_{2}$-modified biochar with the change in the $\mathrm{pH}$ of the solution from 2 to 5 . A $\mathrm{Zn}^{2+}$ removal concentration of $2.18 \mathrm{ppm}$ was achieved at a $\mathrm{pH}$ of 3 and a maximum of $6.27 \mathrm{ppm}$ at a $\mathrm{pH}$ of 4.5. Interestingly, for the $\mathrm{H}_{3} \mathrm{PO}_{4}$-activated macadamia biochar, the lowest $\mathrm{Zn}^{2+}$ removal concentration was observed to be $1.33 \mathrm{ppm}$ at the $\mathrm{pH}$ of 2.5 and the highest removal efficiency was at the $\mathrm{pH}$ of 4.5 with a removal concentration of $6.05 \mathrm{ppm}$. These results indicate that the most suitable $\mathrm{pH}$ solution for the removal of $\mathrm{Zn}^{2+}$ from the aqueous solution by activated macadamia biochar was around 4.5 and the $\mathrm{H}_{2} \mathrm{O}_{2}$-activated biochar reveals the highest $\mathrm{Zn}^{2+}$ adsorption capability.

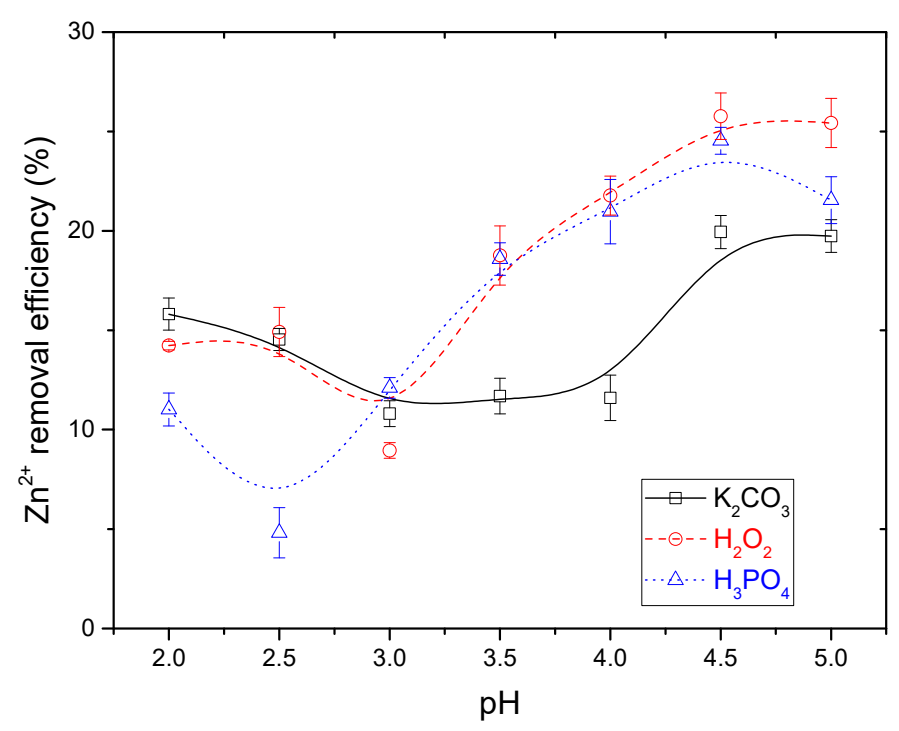

Figure 5. Effect of $\mathrm{pH}$ of the solution on $\mathrm{Zn}^{2+}$ adsorption by chemically modified MCN biochars with an adsorbent dose of $0.3 \mathrm{~g} / \mathrm{L}$ and adsorption time of one hour.

Figure 6 shows the effect adsorbent concentrations of the chemically modified MCN biochars on the removal performance of $\mathrm{Zn}^{2+}$ from the aqueous solution at a $\mathrm{pH}$ of 4.5 for one hour. The $\mathrm{Zn}^{2+}$ removal concentrations increased with the increase in adsorbent dosed. For the $\mathrm{K}_{2} \mathrm{CO}_{3}$-activated biochar as adsorbent, $\mathrm{Zn}^{2+}$ removal increased significantly in the adsorbent doses ranging from $0.2 \mathrm{~g} / \mathrm{L}$ to $2 \mathrm{~g} / \mathrm{L}$ and reaches a maximum at the adsorbent dose of $2 \mathrm{~g} / \mathrm{L}$ with the highest removal percentage of $45.80 \%$. However, compared to the removal efficiency of $1.8 \mathrm{~g} / \mathrm{L}(45.29 \%)$, this value was not significant, and thus, the optimal $\mathrm{K}_{2} \mathrm{CO}_{3}$-activated biochar concentration for cost-effective adsorption of $\mathrm{Zn}^{2+}$ adsorption was determined to be $1.8 \mathrm{~g} / \mathrm{L}$. This trend was also observed with $\mathrm{H}_{2} \mathrm{O}_{2}$ and $\mathrm{H}_{3} \mathrm{PO}_{4}$-activated MCN biochars as the optimal adsorbent doses were determined to be $1.8 \mathrm{~g} / \mathrm{L}$ for $\mathrm{Zn}^{2+}$ adsorption efficiencies of $57.3 \%$ and $65.56 \%$, respectively.

Figure 7 shows the effect of adsorption time $(0 \mathrm{~min}$ to $120 \mathrm{~min})$ on the $\mathrm{Zn}^{2+}$ removal efficiencies of the chemically modified MCN biochars with the adsorbent content of $1.8 \mathrm{~g} / \mathrm{L}, \mathrm{Zn}^{2+}$ concentration of $30 \mathrm{ppm}$, and a pH of 4.5. Unlike the removal of $\mathrm{Cu}^{2+}$, for which the chemically activated macadamia biochars showed high adsorption speed reaching the equilibrium state only after $30 \mathrm{~min}$, in this case, the adsorption ability of the biochars for $\mathrm{Zn}^{2+}$ oxides were relatively slow. The $\mathrm{Zn}^{2+}$ adsorption efficiencies of $\mathrm{K}_{2} \mathrm{CO}_{3}, \mathrm{H}_{2} \mathrm{O}_{2}$ and $\mathrm{H}_{3} \mathrm{PO}_{4}$-modified macadamia biochars only reached the equilibrium value after $80 \mathrm{~min}$ of adsorption time with the removal concentrations of $12.22 \mathrm{ppm}, 15.48 \mathrm{ppm}$ and $16.42 \mathrm{ppm}$, respectively. 


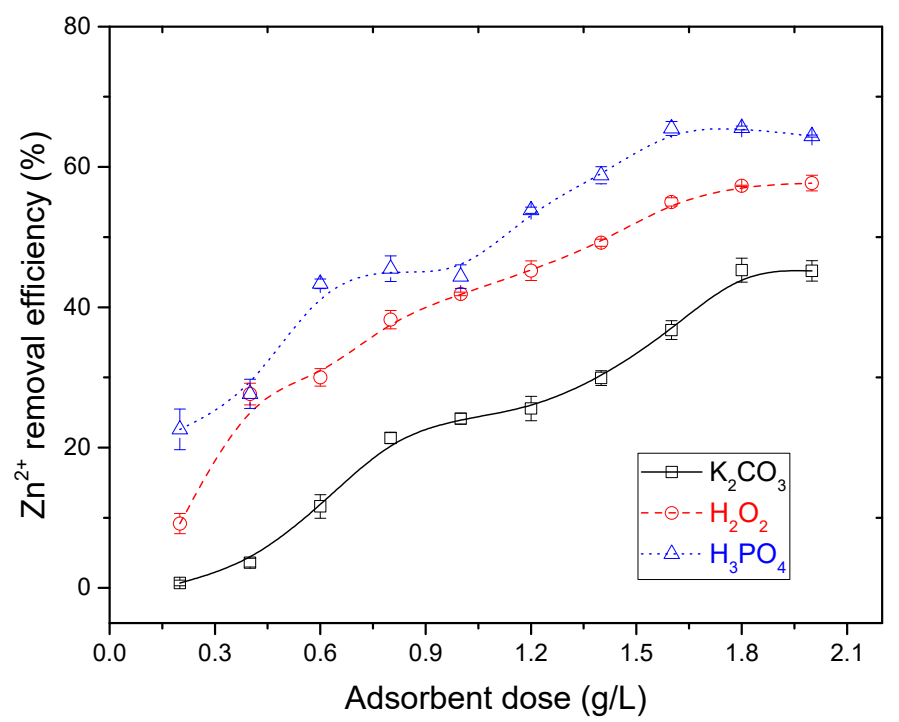

Figure 6. Effects of concentrations of chemically modified $\mathrm{MCN}$ biochars on $\mathrm{Zn}^{2+}$ adsorption performance with an adsorption time of one hour and $\mathrm{pH}$ of the solution of 4.5.

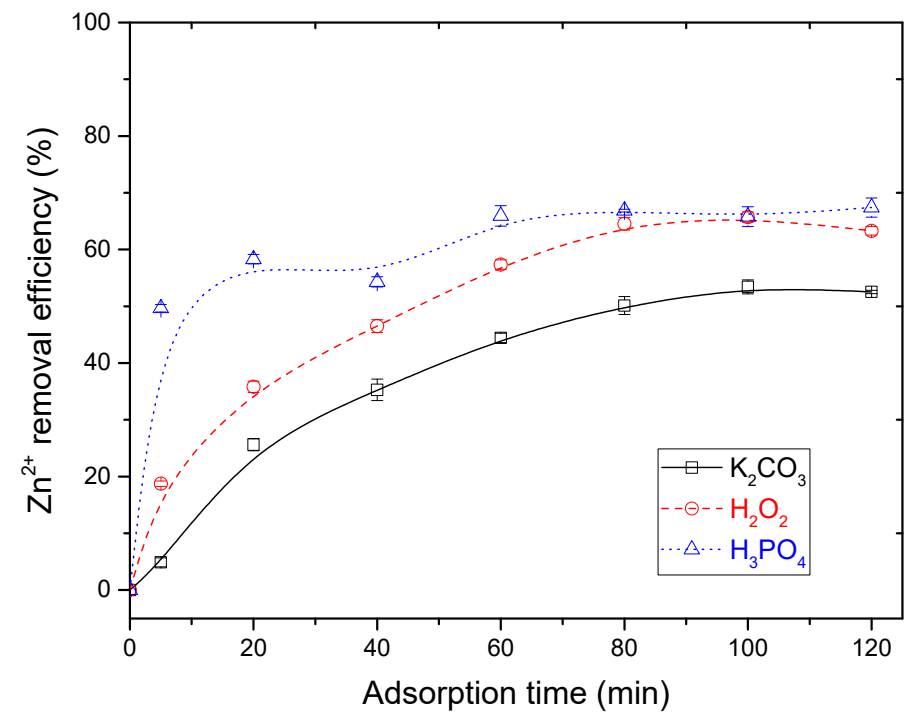

Figure 7. Effect of adsorption time on $\mathrm{Zn}^{2+}$ removal efficiencies by activated MCN biochars with an adsorbent dose of $1.8 \mathrm{~g} / \mathrm{L}$ at a $\mathrm{pH}$ of 4.5 .

The results discussed above lead to the conclusion that the macadamia biochars activated with $\mathrm{H}_{3} \mathrm{PO}_{4}$ show the highest and fastest $\mathrm{Zn}^{2+}$ and $\mathrm{Cu}^{2+}$ adsorption performances, and therefore, can be employed as effective adsorbents for the removal of metal ions from aqueous media.

It is clear from the above results that the $\mathrm{MCN}$ biochars activated with $\mathrm{H}_{3} \mathrm{PO}_{4}$ reveal the highest removal efficiency toward $\mathrm{Cu}^{2+}$ and $\mathrm{Zn}^{2+}$. The adsorption capacity can be roughly estimated with the following equation:

$$
q_{e}=\frac{\left(C_{0}-C_{e}\right) \times V}{m}
$$

where $C_{0}(\mathrm{mg} / \mathrm{L})$ is the initial concentration, $C_{e}(\mathrm{mg} / \mathrm{L})$ is the equilibrium concentration, $V(\mathrm{~L})$ is the solution volume and $m(\mathrm{~g})$ is the mass of the activated MCN biochars. Based on the investigation of adsorbent dosage on the removal efficiency toward $\mathrm{Cu}^{2+}$ and $\mathrm{Zn}^{2+}$ with the adsorption dosage of $0.2 \mathrm{~g} / \mathrm{L}, \mathrm{Cu}^{2+}$ and $\mathrm{Zn}^{2+}$ concentration of $30 \mathrm{mg} / \mathrm{L}$, the adsorption capacity of activated MCN biochars for $\mathrm{Cu}^{2+}$ and $\mathrm{Zn}^{2+}$ are 2.825 and $2.1 \mathrm{mg} / \mathrm{g}$, respectively. These results are slightly higher than the adsorption capacity of the biochar fabricated from the rice husk for the $\mathrm{Cu}^{2+}$ and $\mathrm{Zn}^{2+}$ removal [41]. 


\section{Conclusions}

To summarize, the macadamia biochar was successfully fabricated and modified with $\mathrm{K}_{2} \mathrm{CO}_{3}$, $\mathrm{H}_{2} \mathrm{O}_{2}$ and $\mathrm{H}_{3} \mathrm{PO}_{4}$. The modified-MCN biochars have porous microstructures with an average pore size of $10 \mu \mathrm{m}$. The resultant chemically modified biochars were used as adsorbent and they show high $\mathrm{Cu}^{2+}$ and $\mathrm{Zn}^{2+}$ adsorption performances. The effect of several factors such as the $\mathrm{pH}$ of the solution, adsorption time and adsorbent doses were investigated in detail. The results showed that the optimized $\mathrm{pH}$ of the solution, adsorbent doses and adsorption time for the removal for $\mathrm{Cu}^{2+}$ and $\mathrm{Zn}^{2+}$ are 5, $2 \mathrm{~g} / \mathrm{L}$ and $30 \mathrm{~min}$ and 4.5, $1.8 \mathrm{~g} / \mathrm{L}$ and $80 \mathrm{~min}$, respectively. Of the three $\mathrm{K}_{2} \mathrm{CO}_{3}, \mathrm{H}_{2} \mathrm{O}_{2}$ and $\mathrm{H}_{3} \mathrm{PO}_{4}$ modifiers, the macadamia biochars activated with $\mathrm{H}_{3} \mathrm{PO}_{4}$ had the highest $\mathrm{Cu}^{2+}$ and $\mathrm{Zn}^{2+}$ adsorption performances. With high adsorption efficiencies and inexpensive fabrication from biomass waste, chemically activated macadamia biochar can be used as a promising adsorbent for the effective removal of toxic metal ions in practical applications.

Author Contributions: Conceptualization, M.T.D., D.D.L., D.D.N. and V.K.N.; methodology, M.T.D., T.T.T.N. and X.D.N.; software, M.T.D. and W.J.C.; investigation, M.T.D., D.D.L., D.D.N. and V.K.N.; data curation, M.T.D., T.T.T.N., and X.D.N.; writing-original draft, M.T.D. and D.D.L.; writing-reviewing scientific contents and editing, S.W.C. and W.J.C. All authors have read and agreed to the published version of the manuscript.

Funding: This research is funded by Thu Dau Mot University under grant number ĐT.20-014.

Acknowledgments: The authors are grateful to the research collaboration among universities, institutes and groups of authors.

Conflicts of Interest: The authors declare no conflict of interest exits in the submission of this manuscript.

\section{References}

1. Herrera Melián, J.A. Sustainable Wastewater Treatment Systems (2018-2019). Sustainability 2020, $12,1940$. [CrossRef]

2. Chiou, W.-Y.; Hsu, F.-C. Copper Toxicity and Prediction Models of Copper Content in Leafy Vegetables. Sustainability 2019, 11, 6215. [CrossRef]

3. Rehwoldt, R.; Bida, G.; Nerrie, B. Acute toxicity of copper, nickel and zinc ions to some Hudson River fish species. Bull. Environ. Contaminat. Toxicol. 1971, 6, 445-448. [CrossRef] [PubMed]

4. Vardhan, K.H.; Kumar, P.S.; Panda, R.C. A review on heavy metal pollution, toxicity and remedial measures: Current trends and future perspectives. J. Mol. Liq. 2019, 290, 111197. [CrossRef]

5. Carolin, C.F.; Kumar, P.S.; Saravanan, A.; Joshiba, G.J.; Naushad, M. Efficient techniques for the removal of toxic heavy metals from aquatic environment: A review. J. Environ. Chem. Eng. 2017, 5, 2782-2799. [CrossRef]

6. Kurniawan, T.A.; Sillanpää, M.E.; Sillanpää, M. Nanoadsorbents for remediation of aquatic environment: Local and practical solutions for global water pollution problems. Crit. Rev. Environ. Sci. Technol. 2012, 42, 1233-1295. [CrossRef]

7. Ukanwa, K.S.; Patchigolla, K.; Sakrabani, R.; Anthony, E.; Mandavgane, S. A Review of Chemicals to Produce Activated Carbon from Agricultural Waste Biomass. Sustainability 2019, 11, 6204. [CrossRef]

8. Malara, A.; Paone, E.; Frontera, P.; Bonaccorsi, L.; Panzera, G.; Mauriello, F. Sustainable Exploitation of Coffee Silverskin in Water Remediation. Sustainability 2018, 10, 3547. [CrossRef]

9. Tran, T.H.; Le, A.H.; Pham, T.H.; Nguyen, D.T.; Chang, S.W.; Chung, W.J.; Nguyen, D.D. Adsorption isotherms and kinetic modeling of methylene blue dye onto a carbonaceous hydrochar adsorbent derived from coffee husk waste. Sci. Total Environ. 2020, 725, 138325. [CrossRef]

10. Inyang, M.I.; Gao, B.; Yao, Y.; Xue, Y.; Zimmerman, A.; Mosa, A.; Pullammanappallil, P.; Ok, Y.S.; Cao, X. A review of biochar as a low-cost adsorbent for aqueous heavy metal removal. Crit. Rev. Environ. Sci. Technol. 2016, 46, 406-433. [CrossRef]

11. Tripathi, M.; Sahu, J.N.; Ganesan, P. Effect of process parameters on production of biochar from biomass waste through pyrolysis: A review. Renew. Sustain. Energy Rev. 2016, 55, 467-481. [CrossRef]

12. Laird, D.A.; Brown, R.C.; Amonette, J.E.; Lehmann, J. Review of the pyrolysis platform for coproducing bio-oil and biochar. Biofuels Bbioprod. Biorefin. 2009, 3, 547-562. [CrossRef] 
13. González-García, P. Activated carbon from lignocellulosics precursors: A review of the synthesis methods, characterization techniques and applications. Renew. Sustain. Energy Rev. 2018, 82, 1393-1414. [CrossRef]

14. Cataldo, S.; Chiodo, V.; Crea, F.; Maisano, S.; Milea, D.; Pettignano, A. Biochar from byproduct to high value added material-A new adsorbent for toxic metal ions removal from aqueous solutions. J. Mol. Liq. 2018, 271, 481-489. [CrossRef]

15. Paranavithana, G.; Kawamoto, K.; Inoue, Y.; Saito, T.; Vithanage, M.; Kalpage, C.; Herath, G. Adsorption of $\mathrm{Cd} 2+$ and $\mathrm{Pb} 2+$ onto coconut shell biochar and biochar-mixed soil. Environ. Earth Sci. 2016, 75, 484. [CrossRef]

16. Lee, J.E.; Park, Y.-K. Applications of Modified Biochar-Based Materials for the Removal of Environment Pollutants: A Mini Review. Sustainability 2020, 12, 6112. [CrossRef]

17. Fan, F.; Yang, Z.; Li, H.; Shi, Z.; Kan, H. Preparation and properties of hydrochars from macadamia nut shell via hydrothermal carbonization. R. Soc. Open Sci. 2018, 5, 181126. [CrossRef]

18. Bada, S.; Falcon, R.; Falcon, L.; Makhula, M. Thermogravimetric investigation of macadamia nut shell, coal, and anthracite in different combustion atmospheres. J. S. Afr. Inst. Min. Met. 2015, 115, 741-746. [CrossRef]

19. Zhao, L.; Yang, F.; Jiang, Q.; Zhu, M.; Jiang, Z.; Tang, Y.; Zhang, Y. Characterization of modified biochars prepared at low pyrolysis temperature as an efficient adsorbent for atrazine removal. Environ. Sci. Pollut. Res. 2018, 25, 1405-1417. [CrossRef]

20. Ahmadpour, A.; Do, D. The preparation of activated carbon from macadamia nutshell by chemical activation. Carbon 1997, 35, 1723-1732. [CrossRef]

21. Yang, J.; Li, H.; Zhang, D.; Wu, M.; Pan, B. Limited role of biochars in nitrogen fixation through nitrate adsorption. Sci. Total Environ. 2017, 592, 758-765. [CrossRef] [PubMed]

22. Wrobel-Tobiszewska, A.; Boersma, M.; Sargison, J.; Adams, P.; Singh, B.; Franks, S.; Birch, C.; Close, D. Nutrient changes in potting mix and Eucalyptus nitens leaf tissue under macadamia biochar amendments. J. For. Res. 2018, 29, 383-393. [CrossRef]

23. Spokas, K.A.; Baker, J.M.; Reicosky, D.C. Ethylene: Potential key for biochar amendment impacts. Plant Soil 2010, 333, 443-452. [CrossRef]

24. Kumar, U.; Maroufi, S.; Rajarao, R.; Mayyas, M.; Mansuri, I.; Joshi, R.K.; Sahajwalla, V. Cleaner production of iron by using waste macadamia biomass as a carbon resource. J. Clean. Prod. 2017, 158, 218-224. [CrossRef]

25. Sajjadi, B.; Zubatiuk, T.; Leszczynska, D.; Leszczynski, J.; Chen, W.Y. Chemical activation of biochar for energy and environmental applications: A comprehensive review. Rev. Chem. Eng. 2019, 35, 777-815. [CrossRef]

26. Ponnusamy, V.K.; Nagappan, S.; Bhosale, R.R.; Lay, C.-H.; Duc Nguyen, D.; Pugazhendhi, A.; Chang, S.W.; Kumar, G. Review on sustainable production of biochar through hydrothermal liquefaction: Physico-chemical properties and applications. Bioresour. Technol. 2020, 310, 123414. [CrossRef]

27. Rodrigues, L.A.; de Sousa Ribeiro, L.A.; Thim, G.P.; Ferreira, R.R.; Alvarez-Mendez, M.O.; dos Reis Coutinho, A. Activated carbon derived from macadamia nut shells: An effective adsorbent for phenol removal. J. Porous Mater. 2013, 20, 619-627. [CrossRef]

28. Vilas Boas, N.; Casarin, J.; Passarella Gerola, G.; Ricardo Teixeira Tarley, C.; Caetano, J.; Celso Gonçalves, A., Jr.; Cardoso Dragunski, D. Evaluation of kinetic and thermodynamic parameters in adsorption of lead $\left(\mathrm{Pb}^{2+}\right)$ and chromium $\left(\mathrm{Cr}^{3+}\right)$ by chemically modified macadamia (Macadamia integrifolia). Desalin. Water Treat. 2016, 57, 17738-17747. [CrossRef]

29. Ntuli, T.D. Preparation of Chemically Modified Macadamia Nutshells for Adsorptive Removal of Selected Heavy Metals. Ph.D. Thesis, Vaal University of Technology, Vanderbijlpark, South Africa, 2017.

30. Hlungwane, L.; Viljoen, E.L.; Pakade, V.E. Macadamia nutshells-derived activated carbon and attapulgite clay combination for synergistic removal of Cr (VI) and Cr (III). Ads. Sci. Technol. 2018, 36, 713-731. [CrossRef]

31. Maremeni, L.C.; Modise, S.J.; Mtunzi, F.M.; Klink, M.J.; Pakade, V.E. Adsorptive removal of hexavalent chromium by diphenylcarbazide-grafted Macadamia nutshell powder. Bioinorg. Chem. Appl. 2018, 2018, 6171906. [CrossRef]

32. Pakade, V.E.; Ntuli, T.D.; Ofomaja, A.E. Biosorption of hexavalent chromium from aqueous solutions by Macadamia nutshell powder. Appl. Water Sci. 2017, 7, 3015-3030. [CrossRef]

33. Badruddoza, A.Z.M.; Tay, A.S.H.; Tan, P.Y.; Hidajat, K.; Uddin, M.S. Carboxymethyl- $\beta$-cyclodextrin conjugated magnetic nanoparticles as nano-adsorbents for removal of copper ions: Synthesis and adsorption studies. J. Hazard. Mater. 2011, 185, 1177-1186. [CrossRef] [PubMed] 
34. Martins, A.C.; Pezoti, O.; Cazetta, A.L.; Bedin, K.C.; Yamazaki, D.A.S.; Bandoch, G.F.G.; Asefa, T.; Visentainer, J.V.; Almeida, V.C. Removal of tetracycline by NaOH-activated carbon produced from macadamia nut shells: Kinetic and equilibrium studies. Chem. Eng. J. 2015, 260, 291-299. [CrossRef]

35. Madhava Rao, M.; Ramesh, A.; Purna Chandra Rao, G.; Seshaiah, K. Removal of copper and cadmium from the aqueous solutions by activated carbon derived from Ceiba pentandra hulls. J. Hazard. Mater. 2006, 129, 123-129. [CrossRef]

36. Pehlivan, E.; Özkan, A.M.; Dinç, S.; Parlayici, Ş. Adsorption of $\mathrm{Cu}^{2+}$ and $\mathrm{Pb}^{2+}$ ion on dolomite powder. J. Hazard. Mater. 2009, 167, 1044-1049. [CrossRef]

37. Özverdi, A.; Erdem, M. Cu ${ }^{2+}, \mathrm{Cd}^{2+}$ and $\mathrm{Pb}^{2+}$ adsorption from aqueous solutions by pyrite and synthetic iron sulphide. J. Hazard. Mater. 2006, 137, 626-632. [CrossRef]

38. Imamoglu, M.; Tekir, O. Removal of copper (II) and lead (II) ions from aqueous solutions by adsorption on activated carbon from a new precursor hazelnut husks. Desalination 2008, 228, 108-113. [CrossRef]

39. Thakur, L.S.; Parmar, M. Adsorption of heavy metal $\left(\mathrm{Cu}^{2+}, \mathrm{Ni}^{2+}\right.$ and $\left.\mathrm{Zn}^{2+}\right)$ from synthetic waste water by tea waste adsorbent. Int. J. Chem. Phys. Sci. 2013, 2, 6-19.

40. Singha, B.; Das, S.K. Adsorptive removal of $\mathrm{Cu}(\mathrm{II})$ from aqueous solution and industrial effluent using natural/agricultural wastes. Colloids Surf. B Biointerfaces 2013, 107, 97-106. [CrossRef]

41. Ngah, W.W.; Hanafiah, M.M. Removal of heavy metal ions from wastewater by chemically modified plant wastes as adsorbents: A review. Bioresour. Technol. 2008, 99, 3935-3948. [CrossRef]

(C) 2020 by the authors. Licensee MDPI, Basel, Switzerland. This article is an open access article distributed under the terms and conditions of the Creative Commons Attribution (CC BY) license (http://creativecommons.org/licenses/by/4.0/). 